\title{
The Improvement of Students' Academic Performance by Using Social Media through Collaborative Learning in Malaysian Higher Education
}

\author{
Waleed Mugahed Al-rahmi ${ }^{1}$, Mohd Shahizan Othman ${ }^{1} \&$ Mahdi Alhaji Musa ${ }^{1}$ \\ ${ }^{1}$ Department of Information System, Universiti Teknologi Malaysia, Johor Bahru, Malaysia \\ Correspondence: Waleed Mugahed Al-rahmi, Faculty of Computing, Universiti Teknologi Malaysia, 81310 \\ UTM, Johor Bahru, Malaysia. E-mail: abumunir82@yahoo.com
}

Received: January 28, 2014 Accepted: February 23, 2014 Online Published: March 26, 2014

doi:10.5539/ass.v10n8p210 URL: http://dx.doi.org/10.5539/ass.v10n8p210

\begin{abstract}
The social media have infiltrated the $21^{\text {st }}$ century generations of Internet users, making it a very active means of communications, particularly among students of higher institutions of education. Consequently, academic activities in institutions and faculties are increasingly carried out through the social networks, such as Facebook, twitter and LinkedIn. These are essentially used in order to connect with current and prospective students and also to deliver instructional content. Questions arise about the impact of social media on academic performance and the possibility of using them as an effective pedagogical tool to improvement academic performance. A pilot study of undergraduate and postgraduate students at Universiti Teknologi Malaysia (UTM) was carried out to obtain preliminary results of usage of social media currently. Results obtained show that social media affects positively and significantly collaborative learning with interaction with peers, interaction with supervisor, engagement, perceived ease of use, and perceived usefulness.
\end{abstract}

Keywords: social media, students' academic performance, collaborative learning and higher education

\section{Introduction}

Social media is generally used on a regular basis by millions of people across the globe for different reasons. A big portion of social media users is made up of youths where most of them are college students. In fact, a recent survey of 3000 students from across the US shows that $90 \%$ of college students use Facebook and $37 \%$ use Twitter (Dahlstrom et al., 2011). Given the popularity of social media, a number of universities are using them as marketing program and as a means of communication with current and prospective students and also the alumni. University professors are embracing the social media for effective discussions and dealing with their students in matters relating to academics and improving learning benefits through better communication within and outside the classes. However, recent reviews show over-participation or addiction of students to social networking may have a negative impact on their academic performance (Kirschner \& Karpinski, 2010). This has spurred discussion among faculties, across disciplines and from various schools in relation to the effectiveness and stability of social media as a teaching tool.

Considering the standard undergraduate class in which the instructor's goal is to create a fascinating atmosphere that encourages deep learning, throughout class periods most students are usually on Facebook instead of following along with the instructor's demonstration. Some are even bold enough to respond to a mobile phone call in school although most professors are strict about that.

The purpose of this study is to develop a general framework that defines the key direct and indirect drivers of academic performance. Particular interest is specifically based on the impact of collaborative learning using social media. Observations of students and a search of current literature indicate that students' academic performance is a function of collaborative learning, skills of students, students' characteristics, academic competence and time spent on social media use.

\section{Literature Review}

There has been great concern among concerned individuals in education and parents on the growing usage of Facebook and its effect on pedagogy specifically among students in colleges (Abramson, 2011; Kamenetz, 2011). 
Studies have shown that Facebook is the most popular social tool used where 85 to $99 \%$ of college students use it for different purposes (Hargittai, 2008; Jones \& Fox, 2009; Matney \& Borland, 2009).

On this basis, curriculum developers have been examining the learning environments and different activities with the aim of internationalizing learning and teaching in the way that will recognize and respect and also usefully engage the ethnic and cultural diversity of students. Social media communication and collaborative technologies capabilities such as threaded bulletin boards are used to support internationalized teaching and learning and have been found to be effective in this case (Leask, 2004). The value of interactive social media technologies in high institutions of learning is now recognized in the way that teaching and learning strategies is in an increasingly globalized process (Gray et al., 2010). One of the most commonly cited benefits of social media by scholars is their ability to facilitate collaborative learning and communication among peers and with people outside academia (Collins \& Hide, 2010; Rowlands et al., 2011).

Another frequently reported advantage of social networking is its remarkable ability to facilitate information distribution. Among the examples include blogging tools which are used by many students to disseminate information within their area, their peers and also to everyone globally (Bukvova et al., 2010; Luzon, 2009). The ability to explore unasked questions inside a less formal atmosphere, getting a strong voice through web technology, and getting a location to go over issues within an open, public format are other provisions of social media (Kirkup, 2010). Other than communication, scholarly Twitter users cite information distribution among the primary advantages of social networking and have proven to become popular especially in academic conferences (Letierce et al., 2010; Ross et al., 2011). Despite the fact that using social networking in academia has introduced enormous benefits, it is not without some cons and concerns. It is reported that the most affecting on in using social networking from the scientific studies are the possibility of spending a lot of time on them and denying other important aspects time they deserve (Rowlands et al., 2011).

The primary advantage of choosing social networking to aid learning and teaching can only be fully achieved with existence of clear awareness that stipulates the dos and don'ts so as to ensure that whatever students engage in are aimed at gaining the educational pros of the social media (Rutherford, 2010). In most cases the prospective benefits have been achieved where institutions of higher learning regulate to a certain level the use of social media (Kear, 2011). However, due to the rapid growth of usage of social media many institutions of learning have not created strategies for using social media; this is dangerous and should be revisited (Chretien et al., 2009).

\subsection{Social Media for Academic Purpose}

Social networking is an expression of the 21 st century used broadly to define a number of technological tools that stress the social facets in form of a funnel for communication, collaborative learning, and inventive expression; this is also to boost education in higher institution of learning (Dabbagh \& Reo, 2011; Al-rahmi \& Othman, 2013b).

Social networking is playing a big role in boosting academic like in social sciences and in education systems as a whole. Many studies have addressed different aspects of using social networking at various academic and social levels. The accessible literature on social media provides useful suggestions of its application in higher institutions of education (Hamid et al., 2011). Social media may be applied by academicians in various ways, like the Facebook was recommended as a way of communication for getting together with students (Mack, 2007) Undergraduate students of IT attest that social networking has continuously improved their academic success from 2007 to 2010 (Smith \& Caruso, 2010). Most students in higher institutions of learning wish their institutions alter their means of comm. unication to social networks for strengthening class instruction because it is where they spend most of the time. According to (Madge et al., 2009) states that, social media usage enhances educational access and interaction and it fills the learning gap informally between students and the instructors (Bull et al., 2008).

Integrating social media for both entertainment and learning is common among students in higher level of education. College students use various social media applications to extent that it is now an indispensable part of their everyday life for personal and learning purposes (Cao \& Hong, 2011; Dahlstrom, 2012). Mobile technologies and smart phones interweave social media in their palms and at their simple and customized command (Dahlstrom, 2012).

Many academicians have a fear that time spent on social media is beyond the required time, this may lead to plagiarism and privacy issues and in most cases contribute minimally to actual student learning outcomes. They often view the using social media as superfluous or simply not conducive for better learning outcomes (Moran et al., 2012). Studies have proved that most students invest time and efforts on social networks in building 
relationships around on shared interests and on same grounds (Maloney, 2007). It has convinced some experts in education that to incorporate social media towards the conventional interaction and dialogue between students and teachers simplifies most of the difficulties used to be in education. According to, some also have even welcomed the capability of social media services to provide teachers a forum for simple networking and positive networking with students (Lemeul, 2006).

\section{Conceptual Framework and Hypotheses}

This study accounts for a brief discussion on the contents in the suggested framework for evaluating students' academic performance by the use of social media through collaborative learning in higher institutions of learning is presented. However, the investigation of this research finds that social media integration relates to the students' academic performance in their research, this is true through social media variables observed for being utilized through collaborative learning to improve the students' academic performance. The variables observed in this study are: Interactive with peers, Interactive with teachers, Engagement, Perceived ease of use and Perceived usefulness, Influence student's satisfaction, and academic performance of students.

Similarly, a conceptual framework that identifies instruments by which using social networking influences students' academic performance through collaborative learning is supplied which is illustrated in figure 1 . Student awareness from a perspective of peers' interaction, interactive with teachers, engagement in educative related aspects, Positive Attitude, Perceived ease of use and Perceived usefulness that is derived from using social media to promote active collaborative learning is a suggestion of this study. In addition, of enhancement of which ultimately results oriented and improvement in academic performance of students. Social media increases the quality of perceived interaction within the class both among students interaction with peers and between students and also the teacher interaction (Banks, 2006). It has been mentioned in a number of literature that interaction is a critical aspect in all training processes. It also encourages students to have the class active collaborative learning and creates a sustained behavior participation in mastering activities and students engagement, Positive Attitude, Perceived ease of use and Perceived usefulness of using social media for collaborative learning (Carnaghan \& Webb, 2007; Guthrie \& Carlin, 2004; Yanli et al., 2010; Davis, 1989). The existence of these components is instrumental on active collaborative learning to improving students' academic performance in their research.

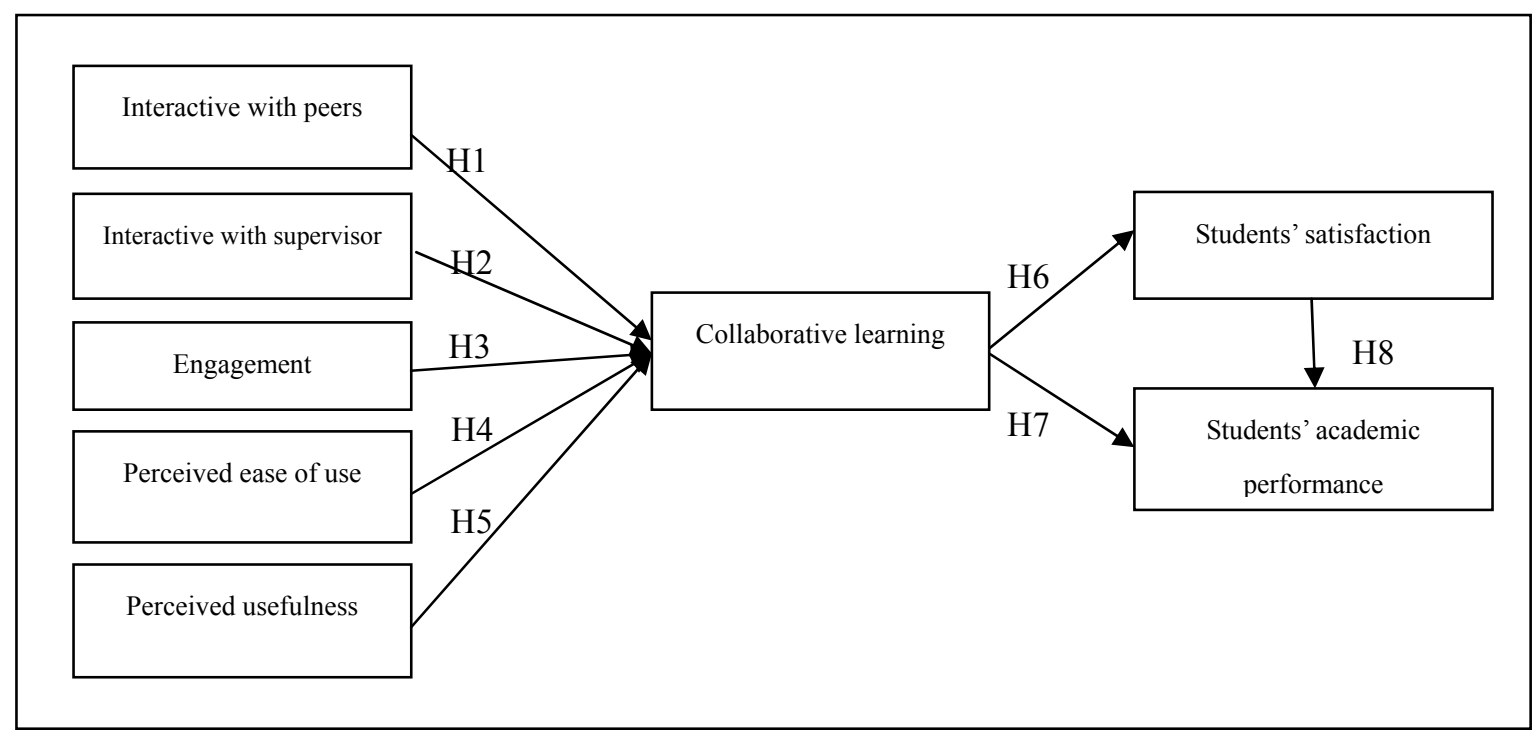

Figure 1. Conceptual framework

\subsection{Interactivity with Peers and Teachers}

Traditional learning techniques can interrupt smooth interactions within the class (Cotner et al., 2008). In addition, limited class time, rigid seating plans and students' reservations about speaking in school are really known as vital obstacles towards class interaction (Draper \& Brown, 2004). However, advanced technologies have transformed the way students interact in classes and outside classes, this consist of new choices to enhance 
interaction. Aiding interaction is important because it results in better and even more effective learning and might be an essential way to obtain success in education. (Bannan, 2002; Siau et al., 2006; Chou, 2003; Siau et al., 2006). This idea has formerly been one of the greatest pedagogical setbacks within the class, designed for bigger classes and technology-related courses. When interaction is obtained within the learning activity, students are motivated to understand, and also more conscious, participative and more susceptible to changing ideas together with fellow students. Consequently, interaction influences student learning benefits (Liu, 2003; Erickson \& Siau, 2003; Haseman et al., 2002; Arcas et al., 2013; Al-rahmi \& Othman, 2013b). Considering conceptual aspect, the idea of integration may be relevant nevertheless the specific ways in which commuting students integrate can vary substantially from students who reside on campus to off campus students, with socio-academic moments as possibly more pivotal for just two-year students (Deil-Amen, 2011). Of those students, the conventional and the idea of interactions with peers and faculty held more appeal and purpose it performs often and depth of connection.

H1. Interactivity with peers as a result of using social media improves students' academic performance through collaborative learning.

H2. Interactivity with teachers as a result of using social media improves students' academic performance through collaborative learning.

\subsection{Student Engagement}

According to Astin (1984) engagement was defined as the quantity of physical and mental energy that a student devotes towards the academic experience. This theory of student engagement that took its origin from the potency of any educational practice is proportional to all that is practiced to improve student engagement. Engagement is seen today as the energy an individual student puts in educational activities which are empirically associated with preferred college final results (Kuh, 2009). Engagement includes various factors, such as the academic experience with college, interactions with faculty, participation in activities within the class, and interaction with peers. Kuh (2009) added that there are two major aspects these are: in-class or academic engagement and out-of-class engagement in educationally relevant or co-curricular activities, each of which are essential to students' success.

Students engagement represent both the time and energy students invest in activities objected towards educational purposes (Kuh et al., 2007). The study further suggests that due to peer group nature influential student can influence other students through the use of social media. Institutions should therefore take decisive actions to harness and shape this influence so that it is educationally purposeful and helps to reinforce academic performance.

H3. Engagements as a result of using social media improve students' academic performance through collaborative learning.

\subsection{Perceived Ease of Use}

Perceived simplicity is a term used to denote "the degree that the mark user needs the prospective system to become free from effort" (Davis, 1989). And (Mayer et al., 1995) defines trust because the readiness of the party to become susceptible to those things of some other party. Thus, customers might depend on the social networking provider not to abuse their information because of its personal gain. Technology Acceptance Model (TAM) came from a theory of reasoned action, and could be regarded as a special situation of simply two salient values: perceived simplicity of use and perceived effectiveness. The predictive energy of perceived simplicity of use and perceived effectiveness for users' technology acceptance continues to be empirically confirmed by many studies. Particularly, users' perceived simplicity of use improves their perceived effectiveness and both constructs considerably improve users' intention to simply accept we've got the technology (Yanli et al., 2010; Al-rahmi \& Othman, 2013c).

H4. Perceived ease of using of social media improves students' academic performance through collaborative learning.

\subsection{Perceived Usefulness}

According to Davis (1989), Perceived effectiveness and usefulness is a degree at which a person thinks as he uses a particular system to facilitate and improve his performance. It further means that, the social media is used in boosting pedagogical effectiveness within the class. Studies in the past revealed that perceived effectiveness helps in utilization of social media on collaborative learning. In another finding, (Boulos et al., 2006; Al-rahmi \& Othman, 2013c) posits that Perceived effectiveness relates to how an individual thinks in the presence of an optimistic user-performance. The consumer perceives the machine to become an ideal way of carrying out the 
duties (Davis, 1989).

H5. Perceived usefulness of using social media improves students' academic performance through collaborative learning.

\subsection{Collaborative Learning}

There has been wide acceptance and integration of social media into pedagogy in recent years. However, the effectiveness of the social media in improving academic performance in collaborative learning has also been envisaged to have risen substantially. Available studies have shown that social media is a positive tool in enhancing academic performances (Selwyn \& Grant, 2009; Arnold \& Paulus, 2010; Hung \& Yuen, 2010; Mason \& Rennie, 2008; Al-rahmi \& Othman, 2013a). In addition, collaborative learning using the social media such as Facebook, E-mail, twitter etc. facilitates learning and knowledge sharing among students, teachers or trainers to the context in real life situation and experiences.

Furthermore, in deciding whether to use individual or a collaborative learning activity, the amount of cognitive load that a learning task imposes on the learner's cognitive capacity should be the main determining factors students' strong desire for collaborative learning and learning with technology. Therefore their novelty effects may mislead thinking that the social media support collaborative learning (SSCL) outcomes effectively (Zoghi et al., 2010). Laird and Kuh (2005) found that, social media has a significant and positive potential of engaging learners as well impacting on their academic performance. Johnson et al. (2008) stated that collaborative learning depends on groups. This implies that learners differ from group to group. In a situation where you have a serious and active group members it translates to positive outcomes and vice versa.

H6. Collaborative learning as a result of using social media improves students' satisfaction.

H7. Collaborative learning as a result of using social media improves students' academic performance.

\subsection{Student Satisfaction with Social Media Use}

Apparently there seem to be an enhanced trend among users to embrace the social networking sites particularly at college level. It appears to possess transformed communication designs even at local level. Palen (2008) and Palen et al. (2009) stated that social networking can offer new methods for individuals to interact both within and outdoors of the spatial bounds from the event. The popularity of utilizing social networking among college students appears to be growing on a daily basis and a lot of them depend on their usage for interactions and communication. According to (Smith \& Caruso, 2010; Al-rahmi \& Othman, 2013a), it was mentioned that a big ratio of students particularly at greater education level are applying social networking failing to remember regarding their physical, mental and mental health. Nonetheless, country profile and accessibility to the infrastructure play a vital role in the enhanced usage.

\subsection{Students'Academic Performance with Social Media Use}

Junco (2011) maintains that social media across fields of study has a greater impact on academic performance on its users. This is also found to be so among races and among different gender. In fact, social group formation on Facebook have been found to facilitate student development (Junco et al., 2011) there are some exceptional cases in which findings show positive relationships between Facebook and Twitter (Junco et al., 2010; Al-rahmi \& Othman, 2013b) integration to improve learning (Heiberger \& Harper, 2008).

In the study conducted by (Englander et al., 2010), he observed that students spend more time using social media for other purposes rather than for educational use, thus affecting their academic performance. In another study (Nalwa \& Anand, 2003) mentions that students like using the internet for their own purposes and this affects their academic performance. This study is further elaborated by (Karpinski, 2009) whereby they stated that social media users have lower grade rankings than students who never engage in social interactions. However there are general benefits associated with users of social media. (Roblyer et al., 2010) explained that social media are sources of communication among students and lecturers in their respective faculties. Furthermore, (Kolek \& Saunders, 2008) resolved that users of social media who are students have no affected whatsoever with their academic performance.

Kirschner and Karpinski (2010) attempted to study the relationship between Facebook and academic performance. The findings reveal that there is a significant negative relationship between Facebook use and academic performance. Respondents reported spending fewer hours in a week studying on average compared to non-users. Most respondents claimed to use Facebook accounts at least once day. This is in line with findings of (Canales et al., 2009; Junco, 2012).

H8. Students' satisfaction improves students' academic performance of using social media through collaborative 
learning.

\section{Research Method}

The data for this study was collected using a method of survey questionnaire that were administered on 120 Undergraduate and postgraduate students in July/2013. The age-range of the respondents was between 18 and 36 . The sample space consisted of 51 males and 69 females. Students were instructed in the survey to offer information about their experiences and impact of using social media on academic performance through collaborative learning. A quantitative approach and give the students the questionnaire in UTM library was used to draw the data for the study.

\subsection{Respondents}

In this research 120 set of questionnaires was randomly distributed to Undergraduate and postgraduate students from the Universiti Teknologi Malaysia. The analysis of this data was performed by SPSS application (Version-20). The instrument used in this study was designed based on the objectives of the study. It was piloted and the Cronbach's alpha of the reliability and validity of the instrument was put at .855 . This is acceptable and the instrument has met the reliability requirement for the study. The questions which are easy to understand and the answers were divided into five sections to make it clearer.

\subsection{Data Collection Procedures}

A five-point Likert scale ( 1 for strongly disagree to 5 strongly agree) was applied in this study. The questionnaire was fine-tuned with reference to a pilot study carried out with students, and tested before-hand, examines the students' opinions about the use of social media on academic performance through collaborative learning in Malaysian higher education. A questionnaire consisting of 35 items was designed, following minor revisions to the layout; the survey was administered at the end of the semester (2013, July). Each participant was provided with a questionnaire and a brief background to the study.

The table on appendix shows the 35 items were used to measure the constructs included in our framework. Interactivity with peers and the teachers was measured using a subset of four items from (Liu, 2003; McMillan \& Hwang, 2002) Engagement was measured using three items adapted from, (Gallini \& Moely, 2003; Medlin \& Green, 2009) Perceived ease of use and Perceived usefulness was measured using a subset of four items from, (Ajjan \& Hartshorne, 2008). Collaborative learning was measured using four items adapted from, (So \& Brush, 2008) students' satisfaction was measured using seven items from, (Zhu, 2012) and finally, students' academic performance was measured using five items from (MacGeorge et al., 2008; Banks, 2006). The letters INT-P stand for interactivity with peers, letters INT-T stand for interactivity with the teachers, letters ENG engagement, letters PEU perceived ease of use, letters PU perceived usefulness, letters CL collaborative learning, letters SS students' satisfaction and letters SAP students' academic performance.

\section{Result and Discussion}

The relationship between the student academic performance (SAP) with interactivity with peers (INT_P), interactivity with the teacher (INT_T), engagement (ENG), perceived ease of use (PEU), perceived usefulness (PU), collaborative learning (CL) were analyzed. Table 1 shows the Pearson correlation coefficient at $99 \%$ confidence level. The best correlation was found between the students' satisfaction (SS) and students' academic performances (SAP) with engagement (ENG) with correlation coefficient of 0.679 .

Result of Pearson correlation indicated that there is statistically significant positive relationship between interactivity with the teachers and interactivity with peers $(\mathrm{r}=0.573, \mathrm{P}<0.01)$. Results demonstrate that relationship between these two construct is moderate and interactivity with the teachers and interactivity with peer's combination contributing moderately towards students' academic performance. Engagement correlation results with interactivity with peers $(\mathrm{r}=0.463, \mathrm{P}<0.01)$ demonstrate moderate positive relationship, while engagement results with interactivity with the teachers $(r=0.625, \mathrm{P}<0.01)$ demonstrate positive relationship showing that these two construct are contributing moderately towards students' academic performance.

Perceived ease of use correlation results with interactivity with peers $(r=0.411, \mathrm{P}<0.01)$ demonstrate moderate positive relationship, while perceived ease of use results with interactivity with the teachers $(r=0.314, P<0.01)$ weaknesses, the correlation results but correlation results with engagement $(\mathrm{r}=0.458, \mathrm{P}<0.01)$. Perceived usefulness correlation results with interactivity with peers $(\mathrm{r}=0.382, \mathrm{P}<0.01)$ demonstrate moderate positive relationship, while perceived usefulness results with interactivity with the teachers $(r=0.457, P<0.01)$ the correlation results but correlation results with engagement $(\mathrm{r}=0.430, \mathrm{P}<0.01)$ and the correlation results with perceived ease of use $(r=0.366, P<0.01)$. Similarly, construct of collaborative learning correlation results with interactivity with peers $(\mathrm{r}=.496, \mathrm{P}<0.10)$, interactivity with the teachers $(\mathrm{r}=.543, \mathrm{P}<0.10)$ with the 
engagement $(\mathrm{r}=0.528, \mathrm{P}<0.10)$ Perceived ease of use correlation results $(\mathrm{r}=.359, \mathrm{P}<0.10)$ and while perceived usefulness results $(\mathrm{r}=.473, \mathrm{P}<0.10)$ demonstrate positive and significant relationship. the dependent variable students' satisfaction has positive and significant correlation with interactivity with peers $(\mathrm{r}=.347, \mathrm{P}<0.10)$, interactivity with the teachers $(\mathrm{r}=.425, \mathrm{P}<0.10)$ with the engagement $(\mathrm{r}=0.421, \mathrm{P}<0.10)$ perceived ease of use correlation results $(\mathrm{r}=.171, \mathrm{P}<0.10)$ weaknesses correlation results, while perceived usefulness results $(\mathrm{r}=.414$, $\mathrm{P}<0.10)$ and with collaborative learning $(\mathrm{r}=.290, \mathrm{P}<0.10)$. While the dependent variable students' academic performance has positive and significant correlation with collaborative learning $(\mathrm{r}=0.555, \mathrm{P}<0.01)$ and positive correlation with collaborative learning. Correlation results of students' academic performance with interactivity with peers $(\mathrm{r}=0.597, \mathrm{P}<0.01)$; interactivity with the teachers $(\mathrm{r}=0.566, \mathrm{P}<0.01)$; engagement $(\mathrm{r}=0.679, \mathrm{P}<$ $0.01)$, perceived ease of use correlation results $(\mathrm{r}=.415, \mathrm{P}<0.10)$ correlation results, while perceived usefulness results $(\mathrm{r}=.397, \mathrm{P}<0.10)$ and with students' satisfaction $(\mathrm{r}=.495, \mathrm{P}<0.10)$. So the positive and significant correlation with engagement.

These results highlight that students' academic performance relationship with interactivity with peers, interactivity with the teachers and the engagement, is contributing to improve students' academic performance. These results highlight that collaborative learning relationship with interactivity with peers, interactivity with the teachers, the engagement, perceived ease of use, and perceived usefulness is contributing towards improvement students' satisfaction and students' academic performance. Figure 2 indicate that interactivity with peers positively and significantly with collaborative learning $(\beta 2=0.143, \mathrm{p}<0.05)$ While support the interaction among the students may improve the students' academic performance through the collaborative learning. Interactivity with teachers positively and significantly with collaborative learning was $(\beta 3=0.130, p<0.05)$.

The interaction between students and teachers found to be lower than interactivity with peers. The engagement has positively and significantly with collaborative learning with standardized beta coefficients was $(\beta 3=0.352, \mathrm{p}$ $<0.05)$. Perceived ease of use has significantly with collaborative learning $(\beta 3=0.052, \mathrm{p}<0.05)$ and the perceived usefulness has weaknesses significantly with collaborative learning $(\beta 3=0.019, p<0.05)$, the collaborative learning with students' satisfaction has good significantly $(\beta 3=0.223, p<0.05)$, the collaborative learning with students' academic performance has also good significantly $(\beta 3=0.290, p<0.05)$, and positively and significantly between students' satisfaction and students' academic performance was $(\beta 3=0.154, p<0.05)$. In line with the outcome of this study to understand students' academic performance by using social media in higher education, the following have been discovered: To acquire a general satisfaction of social media since it encourages and facilitates student utilization of social media for collaborative learning, and boost the education and experience with a students. In terms of interactivity with peers on social media and acquired a higher percentage when it comes to students' academic performance at University since it influences it to be simple for student to go over questions along with other students through social media It is easy to networking with peers and interact with them because it is the same age, class and education level.

Table 1. Descriptive statistics and correlations

\begin{tabular}{lllllllll}
\hline & INT_P & INT_T & ENG & PEU & PU & CL & S.S & SAP \\
\hline INT_P & 1 & & & & & & & \\
INT_T & $.573^{* *}$ & 1 & & & & & & \\
ENG & $.463^{* *}$ & $.625^{* *}$ & 1 & & & & & \\
PEU & $.411^{*}$ & .314 & $.458^{* *}$ & 1 & & & & \\
PU & $.382^{*}$ & $.457^{* *}$ & $.430^{* *}$ & $.366^{*}$ & 1 & & & \\
CL & $.496^{* *}$ & $.543^{* *}$ & $.528^{* *}$ & $.359^{*}$ & $.473^{* *}$ & 1 & & \\
S.S & $.347^{*}$ & $.425^{* *}$ & $.421^{* *}$ & .171 & $.414^{* *}$ & .290 & 1 & \\
SAP & $.597^{* *}$ & $.566^{* *}$ & $.679^{* *}$ & $.415^{*}$ & $.397^{*}$ & $.555^{* *}$ & $.465^{* *}$ & 1 \\
\hline
\end{tabular}

**. Correlation is significant at the 0.01 level (2-tailed).

*. Correlation is significant at the 0.05 level (2-tailed).

In terms of the students' academic performance with engagement acquired a typical percentage when it comes to academic performance of students at University since it provides coalition and sharing of knowledge in the class and library by using social media at any time. The collaborative learning with social media usage and acquired an average percentage when it comes to academic performance of students at University since it helps making 
the students feel confident enough to present the social media by collaborative between peers, teachers and engagement within the class.

In terms perceived ease of use social media also has acquired an average percentage when it comes to academic performance of students, the perceived usefulness of social media when it comes to academic performance of students at University with weakness value.

Finally, In terms of the students' academic performance with interactivity with teachers of utilizing social media and acquired a lowest percentage sometimes not allowed to communicate with teachers or shy students, but is good since it provides those more understanding from teachers, and academic achievement in education.

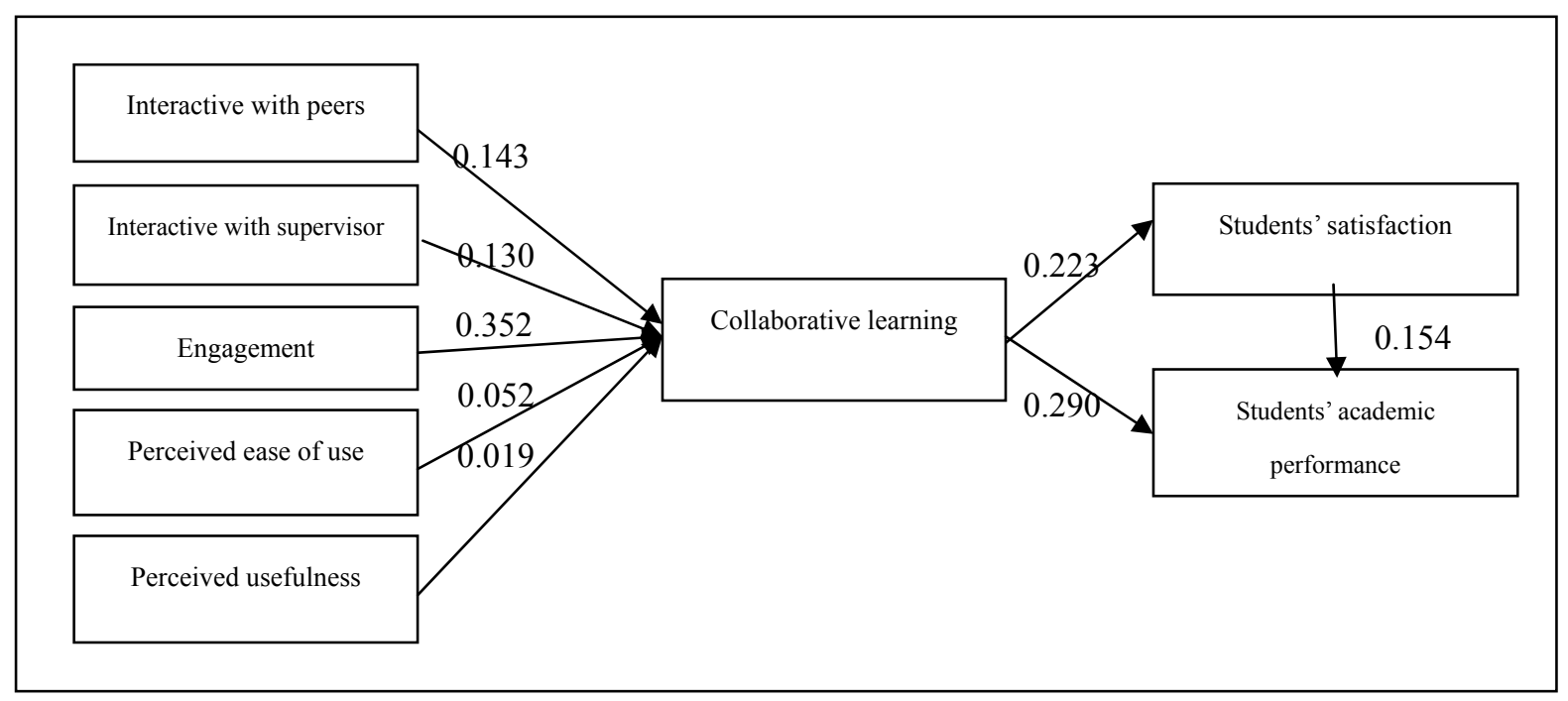

Figure 2. Results for the proposed conceptual framework

\section{Conclusion and Future Work}

This research suggested five predictors of utilizing social networking for collaborative learning to improvement students' academic performance with satisfaction in higher education. The outcomes state $80 \%$ of variance in social media satisfaction to improving academic performance of students could be described through the five predictors. The results attained suggest that research model provided a powerful explanatory energy of social media academic satisfaction for among students. In the results acquired, it may be concluded that social media facilitates the academic experience and collaborative learning with the majority of the participants. The participants may also access material in addition to supplying sufficient content associated with their demands with peers and instructors. Fully engagement in classes towards improving academic performance using social media through collaborative learning in relation to interactive with peers, interactive with teachers, engagement, has resulted in persuasion to ease of use and perceived usefulness is hereby revealed. This paper propose more studies and addition of factors have an effect with collaborative learning to improve students' academic performance as future work (e.g., environmental and cultural). This may be carried out to clarify more in this area also need to study deeper in the future for more than just a single institution of learning but to took a larger sample.

\section{Acknowledgements}

This material is based upon work supported by Instructional Development Grant (IDG) and Research University Grant (RUG) Universiti Teknologi Malaysia, and the Academy of Sciences for the Development World (TWAS) Research Grant under Vote No. 08216,02J 57, and 10-147 RG/ITC/AS_C; UNESCO FR:3240246311. Any opinions, findings, and conclusions or recommendations expressed in this material are those from the authors and do not necessarily reflect on the views of the Universiti Teknologi Malaysia and the Academy of Sciences for the Development World; also supported by Faculty of Marine, Hudaiadah University, Hudaiada, Yemen. 


\section{References}

Ajjan, H., \& Hartshorne, R. (2008). Investigating faculty decisions to adopt Web 2.0 technologies: Theory and empirical tests. Internet and Higher Education, 11, 71-80. http://dx.doi.org/10.1016/j.iheduc.2008.05.002

Al-rahmi, W., \& Othman, M. (2013a). Evaluating student's satisfaction of using social media through collaborative learning in higher education. International Journal of advances in engineering \& technology.

Al-rahmi, W., \& Othman, M. (2013b). The Impact of Social Media use on Academic Performance among university students: A Pilot Study. Journal of information systems research and innovation. Retrieved from http://seminar.utmspace.edu.my/jisri/

Al-rahmi, W., \& Othman, M. (2013c). Using TAM Model to Measure the Use of Social Media for Collaborative Learning. International Journal of Engineering Trends and Technology (IJETT).

Arcas, Buil, Ortega, \& Sese. (2013). Using clickers in class. The role of interactivity, active collaborative learning and engagement in learning performance. Computers and Education, 62, 102-110. http://dx.doi.org/10.1016/j.compedu.2012.10.019

Arnold, N., \& Paulus, T. (2010). Using a social networking site for experiential learning: Appropriating, lurking, modeling and community building. Internet and Higher Education, 13, 188-196. http://dx.doi.org/10.1016/j.iheduc.2010.04.002

Astin, A. (1984). Student involvement: A developmental theory for higher education. Journal of College Student Personnel, 25(4), 297-308.

Banks, D. A. (2006). Reflections on the use of ARS with small groups. In D. A. Banks (Ed.), Audience response systems in higher education (pp. 373-386). http://dx.doi.org/10.4018/978-1-59140-947-2.ch025

Bannan-Ritland, B. (2002). Computer-mediated communication, e-learning, and interactivity: A review of the research. Quarterly Review of Distance Education, 3(2), 161-169.

Boulos, M., Maramba, I., \& Wheeler, S. (2006). Wikis, blogs and podcasts: A new generation of web-based tools for virtual collaborative clinical practice and education. Journal of the American Dietetic Association, 107(4), 553-555.

Bukvova, H., Kalb, H., \& Schoop, E. (2010). What we blog: A qualitative analysis of researchers' weblogs. In Publishing in the networked world: Transforming the nature of communication, 14th international conference on electronic publishing, Helsinki, Finland.

Bull, G., Thompson, A., Searson, M., Garofalo, J., Park, J., Young, J., \& Lee, J. (2008). Connecting informal and formal learning experiences in the age of participatory media. Contemporary Issues in Technology and Teacher Education, 8(2).

Canales, C., Wilbanks, B., \& Yeoman, A. (2009). Facebook Usage in Relation to Personality and Academic Performance. Modern Psychological Studies.

Cao, Y., \& Hong, P. (2011). Antecedents and consequences of social media utilization in college teaching: A proposed model with mixed-methods investigation. On the Horizon, 19(4), 297-306. http://dx.doi.org/10.1108/10748121111179420

Carnaghan, C., \& Webb, A. (2007). Investigating the effects of group response systems in student satisfaction, learning, and engagement in accounting education. Issues in Accounting Education, 22(3), 391-409. http://dx.doi.org/10.2308/iace.2007.22.3.391

Chou, C. (2003). Interactivity and interactive functions in web-based learning systems: A technical framework for designers. British Journal of Educational Technology, 34(3), 265-279. http://dx.doi.org/10.1111/1467-8535.00326

Chretien, K. C., Greysen, S. R., Chretien, J., \& Kind, T. (2009). Online posting of unprofessional conduct by medical students. Journal of the American Medical Association, 302(12), 1309-1315. http://dx.doi.org/10.1001/jama.2009.1387

Collins, E., \& Hide, B. (2010). Use and relevance of web 2.0 resources for researchers. International conference on electronic publishing, 16-18. Helsinki, Finland.

Cotner, S., Fall, B., Wick, S., Walker, J., \& Baepler, P. (2008). Instant feedback assessment methods: Can we improve engagement, enjoyment, and preparation for exams in large-enrollment biology courses? Journal of Science Education and Technology, 17, 437-443. http://dx.doi.org/10.1007/s10956-008-9112-8 
Dabbagh, N., \& Reo, R. (2011). Back to the future: Tracing the roots and learning affordances of social software. Hershey, PA: IGI Global.

Dahlstrom, E. (2012). ECAR study of undergraduate students and information technology. Louisville, CO: EDUCAUSE Center for Applied Research.

Dahlstrom, E., de Boor, T., Grunwald, P., \& Vockley, M. (2011). ECAR: National study of undergraduate students and information technology. Retrieved November 3, 2011, from http://net.educause.edu/ir/library/pdf/ERS1103/ERS1103W.pdf

Davis, F. D. (1989). Perceived usefulness, perceived ease of use and user acceptance of information technology. MIS Quarterly, 13, 319-340. http://dx.doi.org/10.2307/249008

Deil-Amen, R. (2011). Socio-academic integrative moments: Rethinking academic and social integration among two-year college students in career-related programs. Journal of Higher Education, 82(1), 54-91. http://dx.doi.org/10.1353/jhe.2011.0006

Draper, S. W., \& Brown, M. I. (2004). Increasing interactivity in lectures using an electronic voting system. Journal of Computer Assisted Learning, 20, 81-94. http://dx.doi.org/10.1111/j.1365-2729.2004.00074.x

Englander, F., Terregrossa, R. A., \& Wang, Z. (2010). Educational Review, 62(1), 85-96. http://dx.doi.org/10.1080/00131910903519793

Erickson, J., \& Siau, K. (2003). E-education. Communications of the ACM, 46(9), 134-140. http://dx.doi.org/10.1145/903893.903928

Gallini, S. M., \& Moely, B. E. (2003). Service-learning and engagement, academic challenge and retention. Michigan Journal of Community Service Learning, 5-14.

Gray, K., Chang, S., \& Kennedy, G. (2010). Use of social web technologies by international and domestic undergraduate students: Implications for internationalizing learning and teaching in Australian universities. Technology, Pedagogy and Education, 19(1), 31-46. http://dx.doi.org/10.1080/14759390903579208

Guthrie, R. W., \& Carlin, A. (2004). Waking the dead: Using interactive technology to engage passive listeners in the classroom. In Proceedings of the AMCIS, 358. New York: August.

Hamid, S., Waycott, J., Chang, S., \& Kurnia, S. (2011). Appropriating Online Social Networking (OSN) Activities for Higher Education: Two Malaysian Cases. Proceedings ascilite 2011 Hobart.

Hargittai, E. (2008). Whose space? Differences among users and non-users of social network sites. Journal of Computer-Mediated Communication, 13(1), 276-297. http://dx.doi.org/10.1111/j.1083-6101.2007.00396.x

Haseman, W. D., Polatoglu, V. N., \& Ramamurthy, K. (2002). An empirical investigation of the influences of the degree of interactivity of user-outcomes in a multimedia environment. Information Resources Management Journal, 15(2), 31-48. http://dx.doi.org/10.4018/irmj.2002040104

Heiberger, G., \& Harper, R. (2008). Have you face booked Astin lately? Using technology to increase student involvement. New Directions for Student Services, (124), 19-35. http://dx.doi.org/10.1002/ss.293

Hung, H. T., \& Yuen, S. C. Y. (2010). Educational use of social networking technology in Higher education. Teaching in Higher Education, 15(6), 703-714. http://dx.doi.org/10.1080/13562517.2010.507307

Johnson, D. W., Johnson, R. T., \& Holubec, E. J. (2008). Cooperation in the classroom (8th ed.). Edina, MN: Interaction Book.

Jones, S., \& Fox, S. (2009). Generations online in 2009. Data memo. Washington, DC: Pew Internet and American Life Project. Retrieved from http://www.pewinternet.org/w/media//Files/Reports/2009/PIP_Generations_2009.pdf

Junco, R. (2011). The relationship between frequency of Facebook use, participation in Facebook activities, and $\begin{array}{lllll}\text { student engagement. } \quad \text { Computers } \& \quad \text { Education, } & 58, & 162-171 .\end{array}$ http://dx.doi.org/10.1016/j.compedu.2011.08.004

Junco, R. (2012). Too much face and not enough books: The relationship between multiple indices of Facebook use and academic performance. Computers \& Education, 28, 187-198.

Junco, R., Heibergert, G., \& Loken, E. (2010). The effect of Twitter on college student engagement and grades. Journal of Computer Assisted Learning, 27, 119-132. http://dx.doi.org/10.1111/j.1365-2729.2010.00387.x

Kamenetz, A. (2011). Gates Foundation bets on Facebook app to help kids graduate. Fast Company. Retrieved 
from http://www.fastcompany.com/1725665/gates-foundation-bets-on-facebook-app-to-help-kids-graduate

Kear, K. (2010). Online social networking communities: A best practice guide for educators. London: Routledge.

Kirkup, G. (2010). Academic blogging: Academic practice and academic identity. London Review of Education, 8(1), 75-84. http://dx.doi.org/10.1080/14748460903557803

Kirschner, P. A., \& Karpinski, A. C. (2010). Facebook and academic performance. Computers in Human Behavior, 26, 1237-1245. http://dx.doi.org/10.1016/j.chb.2010.03.024

Kolek, E. A., \& Saunders, D. (2008). Online disclosure: An empirical examination of undergraduate Facebook profiles. NAPSA J., (1), 1-25.

Kuh, G. D. (2001). The National Survey of Student Engagement: Conceptual framework and overview of psychometric properties. Bloomington, IN: Center for Postsecondary Research.

Kuh, G. D., Kinzie, J., Cruce, T., Shoup, R., \& Gonyea, R. M. (2007). Connecting the dots: Multi-faceted analyses of the relationship between student engagement results from the NSSE, and the institutional practices and conditions that foster student success. Bloomington, IN: Center for Postsecondary Research.

Laird, T. F. N., \& Kuh, G. D. (2005). Student experiences with information technology and their relationship to other aspects of student engagement. Research in Higher Education, 46(2), 211-232. http://dx.doi.org/10.1007/s11162-004-1600-y

Leask, B. (2004). Internationalization outcomes for all students using information and communication technologies (ICTs). Journal of Studies in International Education, 8(4), $336-351$. http://dx.doi.org/10.1177/1028315303261778

Letierce, J., Passant, A., Breslin, J. G., \& Decker, S. (2010). Understanding how Twitter is used to spread scientific messages. In Proceedings of the WebSci10: Extending the Frontiers of Society On-Line, Raleigh, NC, US, 2010.

Liu, T., Liang, J., Wang, H., Chan, T., \& Wei, L. (2003). Embedding educlick in classroom to enhance interaction. International conference computers in education (ICCE), 117-125.

Liu, Y. (2003). Developing a scale to measure the interactivity of websites. Journal of Advertising Research, 43(3), 207-216.

Luzon, M. J. (2009). Scholarly hyper-writing: The function of links in academic weblogs. Journal of the American Society for Information Science and Technology, 60(1), 75-89. http://dx.doi.org/10.1002/asi.20937

Mack, D., Behler, A., Roberts, B., \& Rimland, E. (2007). Reaching students with Facebook: Data and best practices. Electronic Journal of Academic and Special Librarianship, 8(2).

Madge, C., Meek, J., Wellens, J., \& Hooley, T. (2009). Facebook, social integration and informal learning at university: It is more for socializing and talking to friends about work than for actually doing work. Learning, Media and Technology, 34(2), 141-155. http://dx.doi.org/10.1080/17439880902923606

Maloney, E. (2007). What Web 2.0 can teach us about learning. Chronicle of Higher Education, 53(18).

Mason, R., \& Rennie, F. (2008). E-learning and social networking handbook. London, UK: Routledge.

Matney, M., \& Borland, K. (2009). Facebook, blogs, tweets: How staff and units can use social networking to enhance student learning. Annual meeting of the National Association for Student Personnel Administrators, Seattle, WA.

Mayer, R. C., Davis, J. H., \& Schoorman, F. D. (1995). An Integrative Model of Organizational Trust. Academy of Management Review, 709-734.

McMillan, S. J., \& Hwang, J. (2002). Measures of perceived interactivity: An exploration of the role of direction and communication, user control and time in shaping perceptions of interactivity. Journal of Advertising, 31(3), 29-42. http://dx.doi.org/10.1080/00913367.2002.10673674

Medlin, B., \& Green, K. W. Jr. (2009). Enhancing performance through goal setting, engagement, and optimism. Industrial Management dan Data Systems, 109(7), 943-956. http://dx.doi.org/10.1108/02635570910982292

Moran, M., Seaman, J., \& Tinti-Kane, H. (2012). Blogs, wikis, podcasts and Facebook: How today's higher education faculty use social media, 2012. (Babson Survey Research Group). Boston, MA: Pearson Learning Solutions. 
Nalwa, K., \& Anand, A. P. (2003). Internet addiction in Students: A cause of concern. Cyber psychology and Behavior, 6(6), 653-659. http://dx.doi.org/10.1089/109493103322725441

Palen, L., Vieweg, S., Liu, S., \& Hughes, A. L. (2010). Crisis in a networked world: Features of Computer mediated communication. Social Science Computer Review, 467-480.

Roblyer, M. D., McDaniel, M., Webb, M., Herman, J., \& Witty, J. V. (2010). Findings on Facebook in higher education: A comparison of college faculty and student uses and perceptions of social networking sites. The Internet and Higher Education, 13(3), 134-140. http://dx.doi.org/10.1016/j.iheduc.2010.03.002

Ross, C., Terras, M., Warwick, C., \& Welsh, A. (2011). Enabled backchannel: Conference Twitter use by digital humanists. Journal of Documentation, 67(2), 214-237. http://dx.doi.org/10.1108/00220411111109449

Rowlands, I., Nicholas, D., Russell, B., Canty, N., \& Watkinson, A. (2011). Social media use in the research workflow. Learned Publishing, 24(3), 183-195. http://dx.doi.org/10.1087/20110306

Rutherford, C. (2010). Using Online Social Media to Support Preserves Student Engagement. MERLOT Journal of Online Learning and Teaching, 6(4).

Selwyn, N., \& Grant, L. (2009). Researching the realities of social software use: An introduction. Learning, Media and Technology, 34(2), 79-86. http://dx.doi.org/10.1080/17439880902921907

Siau, K., Sheng, H., \& Nah, F. F. H. (2006). Use of classroom response system to enhance classroom interactivity. IEEE Transactions on Education, 49(3), 398-403. http://dx.doi.org/10.1109/TE.2006.879802

Smith, S. D., \& Caruso, J. B. (2010). The ECAR study of undergraduate students and information technology. EDUCAUSE Center for Applied Research ECAR. Retrieved from http://www.educause.edu/ecar

So, H. J., \& Brush, T. A. (2008). Students' perceptions of collaborative learning, social presence and satisfaction in a blended learning environment: Relationships and critical factors. Computers \& Education, 51(1), 318. http://dx.doi.org/10.1016/j.compedu.2007.05.009

Yanli, J., Yi, Z., \& Yuli, L. (n. d.). Effects of System Characteristics on Users' Self-Disclosure in Social Networking Sites. Information Technology: New Generations (ITNG), 2010 Seventh International Conference on, (12-14), 529-533.

Zhu, C. (2012). Student Satisfaction, Performance, and Knowledge Construction in Online Collaborative Learning.

Zoghi, M., Mustapha, R., \& Maasum, R. (2010). Collaborative Strategic Reading with University EFL Learners. Journal of College Reading and Learning, 41(1), 67-94.

\section{Copyrights}

Copyright for this article is retained by the author(s), with first publication rights granted to the journal.

This is an open-access article distributed under the terms and conditions of the Creative Commons Attribution license (http://creativecommons.org/licenses/by/3.0/). 